\title{
Integrated Biological Control of Tobacco Bacterial Wilt (Ralstonia solanacearum) and Its Effect on Rhizosphere Microbial Community
}

\author{
Yun Hu1*, Chunli Li1 ${ }^{*}$, Xiaoqiong Yang1, Ji Feng'², Lin Wang³, Shouwen Chen1, Yanyan Li2\#, \\ Yong Yang1\# \\ ${ }^{1}$ State Key Laboratory of Biocatalysis and Enzyme Engineering, School of Life Science, Hubei University, Wuhan, China \\ ${ }^{2}$ Tobacco Research Institute of Hubei Province, Wuhan, China \\ ${ }^{3}$ Hubei Tobacco Industry Co., Ltd., Wuhan, China \\ Email: "yangyong@hubu.edu.cn, "yanyanli0025@126.com
}

How to cite this paper: Hu, Y., Li, C.L., Yang, X.Q., Feng, J., Wang, L., Chen, S.W., Li, Y.Y. and Yang, Y. (2021) Integrated Biological Control of Tobacco Bacterial Wilt (Ralstonia solanacearum) and Its Effect on Rhizosphere Microbial Community. Journal of Biosciences and Medicines, 9, 124-142.

https://doi.org/10.4236/jbm.2021.93012

Received: January 30, 2021

Accepted: March 28, 2021

Published: March 31, 2021

Copyright () 2021 by author(s) and Scientific Research Publishing Inc. This work is licensed under the Creative Commons Attribution International License (CC BY 4.0).

http://creativecommons.org/licenses/by/4.0/ (c) (i) Open Access

\begin{abstract}
Biological control agents and soil amendments have been applied to control tobacco bacterial wilt, but the mechanism is not well-known. In the present study, a field experiment was performed to investigate the soil physicochemical properties, disease index (DI) and disease incidence of tobacco bacterial wilt, and rhizosphere microbial community. The results show that the control efficacy of single application of antagonistic bacteria and calcium cyanamide was $46.43 \%$ and $51.92 \%$, respectively. While the combined control efficacy of antagonistic bacteria and calcium cyanamide was $65.79 \%$. Besides, the combined application of antagonistic bacteria and calcium cyanamide could increase soil $\mathrm{pH}$, total $\mathrm{N}$ alkaline $\mathrm{N}$, and exchangeable $\mathrm{Ca}$, which were negatively associated with the microbial diversity, soil-borne pathogenic microorganisms, and incidence of tobacco bacterial wilt. Additionally, the combination of antagonistic bacteria and calcium cyanamide can improve the proportion of some antagonistic microbial species, and these antagonistic microbial species were inversely associated with the DI of tobacco bacterial wilt. In conclusion: The integrated measure may influence soil microbial communities through enhancing soil physicochemical properties and rebuild healthy soil microbial community structure to mitigate tobacco bacterial wilt. The current study presented valuable insights into the mechanisms enhancing soil health in the integrated measure.
\end{abstract}

${ }^{*}$ These authors contributed equally: Yun $\mathrm{Hu}$ and Chunli Li.

${ }^{*}$ Corresponding author. 


\section{Keywords}

Biological Control, Tobacco Bacterial Wilt, Alkaline Fertilizer, Physicochemical Property, Rhizospheric Microorganism

\section{Introduction}

Tobacco bacterial wilt is a soil-borne bacterial infection triggered by Ralstonia solanacearum, which seriously damages the growth of tobacco [1] [2]. Nowadays, tobacco bacterial wilt is distributed in almost all the flue-cured tobacco growing areas in the world, especially in tropical and subtropical tobacco areas. It has been a major devastating disease threatening world tobacco production, which in turn causes great economic loss [3].

Tobacco bacterial wilt has received extensive attention, and many research studied have been reported about how-to restraint the tobacco bacterial wilt in breeding resistant varieties, agricultural control, and chemical control. However, these conventional approaches have a partial effect and are associated with many problems, such as lack of resistant varieties, easy loss of resistance, and the poor control effect of chemical agents, environmental pollution, and so on [4].

The occurrence of tobacco bacterial wilt is not only related to high temperature and high humidity climate but also related to soil types, soil nutrients and continuous cropping [5] [6]. It was reported that continuous harvesting obstacles lead to the imbalance of the number and proportion of microbial populations in the soil and the relative increase of $R$. solanacearum [7]. Besides, the incidence of tobacco bacterial wilt shows a significant positive correlation with $\mathrm{pH}$ values of the soil [8] [9]. Therefore, tobacco bacterial wilt is difficult to be effectively controlled, thus, new methods should be developed for effective control. In recent years, biological control technology has become a research hotspot because of its environmental and ecological safety and its ability to achieve sustainable development of tobacco [10]. Studies show that culturing of antagonistic into bioorganic fertilizers has helped in control of tobacco bacterial wilt. It can not only increase the population of beneficial microorganisms in soil and enhance the disease resistance of tobacco plants but also improve the rhizosphere micro-ecological environment, thus promote root growth and nutrient absorption [11] [12]. Besides, soil amendments can change the physicochemical properties of soil, improve and repair soil ecological environment, affect soil microbes, and reduce the number of pathogens [13] [14]. Due to the complexity of the environment and the limitation of single control methods, the prevention, and control effect of the disease-affected field is not an ideal strategy. Therefore, an integrated approach based on the combination of biological control and soil amendments was proposed as a new method to control tobacco bacterial wilt.

In this study, the antagonistic bacteria and calcium cyanamide were used to repair the tobacco field from bacterial wilt. An effective control mechanism of tobacco bacterial wilt was explored by studying the physicochemical properties 
of root-soil and microbial community structure in rhizosphere soil. To provide further theoretical basis for integrated biological contriol of the tobacco bacterial wilt.

\section{Results}

\subsection{Incidence and Disease Index of Tobacco Bacterial Wilt}

The disease incidence and DI of bacterial wilt in the BA, CC, and BC groups were found remarkably lower than those in the CK group. Moreover, the incidence and DI in the $\mathrm{BC}$ group were also found remarkably lower than those in the BA and CC groups (Figure 1). The control efficacy of the BC group (65.79\%) was observed higher than the BA group (46.43\%) and CC group (51.92\%). These outcomes showed that merging the antagonistic bacteria and calcium cyanamide could control tobacco bacterial wilt more effectively than a single application of antagonistic bacteria and calcium cyanamide.

\subsection{Rhizospheric Soil Physicochemical Properties in Different Treatments}

The physicochemical properties of rhizospheric soil were analyzed (Table S1). The $\mathrm{pH}$, alkaline $\mathrm{N}$, available $\mathrm{K}$, exchangeable $\mathrm{Ca}$, and exchangeable $\mathrm{Mg}$ of rhizospheric soil in the BA, CC, and BC groups were found remarkably higher $(p<$ $0.05)$ than that in the control group. The total $\mathrm{N}$ of rhizospheric soil in the $\mathrm{CC}$ and $\mathrm{BC}$ groups was also observed higher $(p<0.05)$ than that in the control group. However, the organic matter, available $\mathrm{P}$ of rhizospheric soil in the $\mathrm{CC}$, and $\mathrm{BC}$ groups were observed lower $(p<0.05)$ than those in the control group. These results show that the soil physicochemical properties were significantly affected by a single application of antagonistic bacteria, calcium cyanamide, and a combination of the application of antagonistic bacteria and calcium cyanamide. Moreover, applying calcium cyanamide could effectively increase the $\mathrm{pH}$, total $\mathrm{N}$, alkaline $\mathrm{N}$, available $\mathrm{K}$, exchangeable $\mathrm{Ca}$, and exchangeable $\mathrm{Mg}$ of rhizospheric soil.

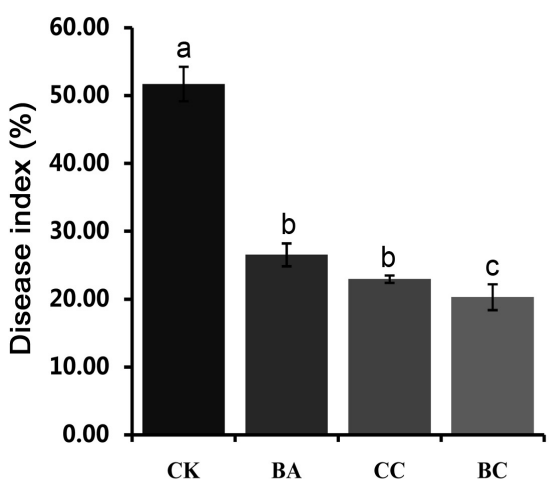

(a)

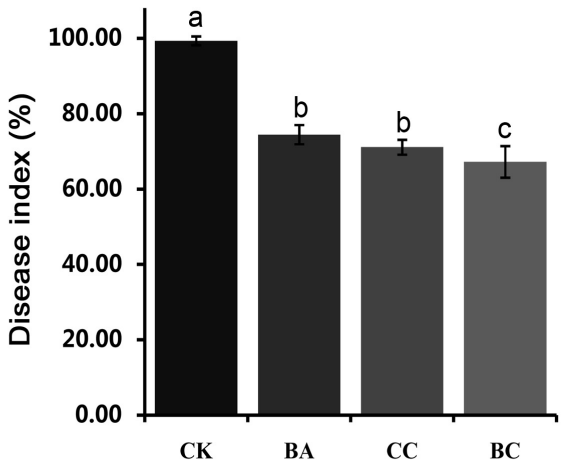

(b)

Figure 1. Disease index (a) and incidence (b) of tobacco bacterial wilt. Data are presented as the means and standard errors amid the samples. Values denoted by the bars with different letters are significantly different at $p<0.05$. 


\subsection{Tobacco Rhizosphere Microbial Community Richness and Diversity}

In total, 6,168,190 fine raw sequences with an average length of 390 bps for bacteria and 350 bps for fungi were obtained after quality filtering (Table S2). The difference between OTUs, Sobs, Chaol, and Shannon index of microbial richness and diversity were analyzed (Table 1). As for the bacteria, the Chaol and Sobs index from the rhizosphere soil of the BC group was observed higher $(p<$ 0.05 ) than those from other groups (BA, CC, and CK). OUT numbers from the rhizosphere soil of the $\mathrm{BC}$ and $\mathrm{CC}$ group showed no significant difference, but all significantly higher $(p<0.05)$ than CK and BA groups. The same trend was observed for the Shannon index. OUT numbers and Sobs, chao1, Shannon index from the bacterial rhizosphere soil of the BC group was higher than other groups. As for the fungal community, the four indexes from the rhizosphere soil of the BC group were the highest. OUT numbers and Sobs, chao1, Shannon index from the fungal rhizosphere soil of the BC group was higher than other groups. These results suggested that the effects of antagonistic bacteria combined with calcium cyanamide were higher than the single application of antagonistic bacteria or calcium cyanamide.

\subsection{The Composition and Structure of Tobacco Rhizosphere Microbial Community}

The leading bacterial phyla found in every treatment were Proteobacteria (37.80\% - 72.28\%), Actinobacteria (6.15\% - 16.18\%), firmicutes $(2.07 \%$ 11.714\%), Acidobacteria (7.75\% - 15.70\%), Gemmatimonadetes (2.90\% - 7.91\%), Chloroflexi (3.23\% - 5.19\%), Bacteroidetes (1.01\% - 3.96\%), and Nitrospirae $(0.71 \%-2.50 \%)$ (Figure 2(a)). The relative population of Gemmatimonadetes, Acidobacteria, firmicutes, Actinobacteria, and Proteobacteria made up almost $81.51 \%-91.16 \%$ amid the 10 predominant bacterial phyla. The relative population of Proteobacteria in the BA, CC, and BC groups was higher than that in the CK group, while the relative population of Actinobacteria, firmicutes, and Gemmatimonadetes in the BA, CC, and BC groups were lower than that in the $\mathrm{CK}$ group, demonstrating that single application of antagonistic bacteria, calcium cyanamide and the combination of antagonistic bacteria and calcium

Table 1. Alpha diversity index of bacteria and fungal in different treatments.

\begin{tabular}{|c|c|c|c|c|c|c|c|c|}
\hline \multirow[b]{2}{*}{ Treatment } & \multicolumn{4}{|c|}{ Bacterial } & \multicolumn{4}{|c|}{ Fungal } \\
\hline & OTUs & $\begin{array}{c}\text { observed_species } \\
\text { (Sobs) }\end{array}$ & chao1 & shannon & OTUs & $\begin{array}{c}\text { observed_species } \\
\text { (Sobs) }\end{array}$ & chao1 & shannon \\
\hline $\mathrm{CK}$ & $2396.0 \pm 84.7 c$ & $2208.3 \pm 90.4 \mathrm{~d}$ & $2184.6 \pm 51.1 \mathrm{~d}$ & $7.6 \pm 0.2 c$ & $659.0 \pm 11.3 \mathrm{~d}$ & $334.7 \pm 13.8 \mathrm{~d}$ & $343.2 \pm 11.7 \mathrm{~d}$ & $3.5 \pm 0.4 b$ \\
\hline $\mathrm{BA}$ & $4122.3 \pm 480.9 b$ & $2988.0 \pm 86.7 c$ & $3056.5 \pm 78.2 c$ & $9.0 \pm 0.2 b$ & $1214.3 \pm 54.2 c$ & $432.0 \pm 6.0 c$ & $449.1 \pm 4.7 c$ & $2.9 \pm 0.2 c$ \\
\hline $\mathrm{CC}$ & $4719.3 \pm 97.6 a$ & $3796.7 \pm 52.4 b$ & $3859.0 \pm 51.6 b$ & $9.7 \pm 0.1 \mathrm{a}$ & $1341.3 \pm 29.6 b$ & $926.0 \pm 34.0 \mathrm{~b}$ & $956.5 \pm 36.8 b$ & $6.1 \pm 0.5 a$ \\
\hline $\mathrm{BC}$ & $4944.3 \pm 88.4 \mathrm{a}$ & $4188.7 \pm 195.6 a$ & $4273.2 \pm 236.5 a$ & $9.7 \pm 0.2 \mathrm{a}$ & $1465.3 \pm 27.6 a$ & $1091.3 \pm 16.2 \mathrm{a}$ & $1125.3 \pm 11.5 a$ & $6.3 \pm 0.3 a$ \\
\hline
\end{tabular}

Values are means of SD $(n=3)$. The different letters in the same column indicate significant differences as determined by LSD test $(p<0.05)$. 


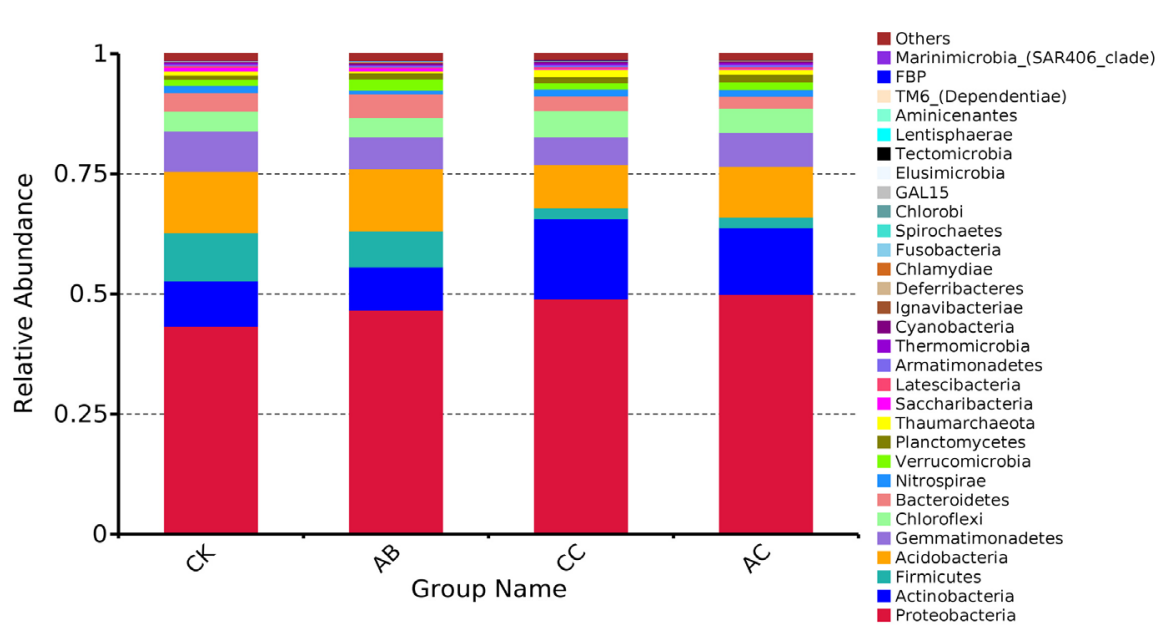

(a)

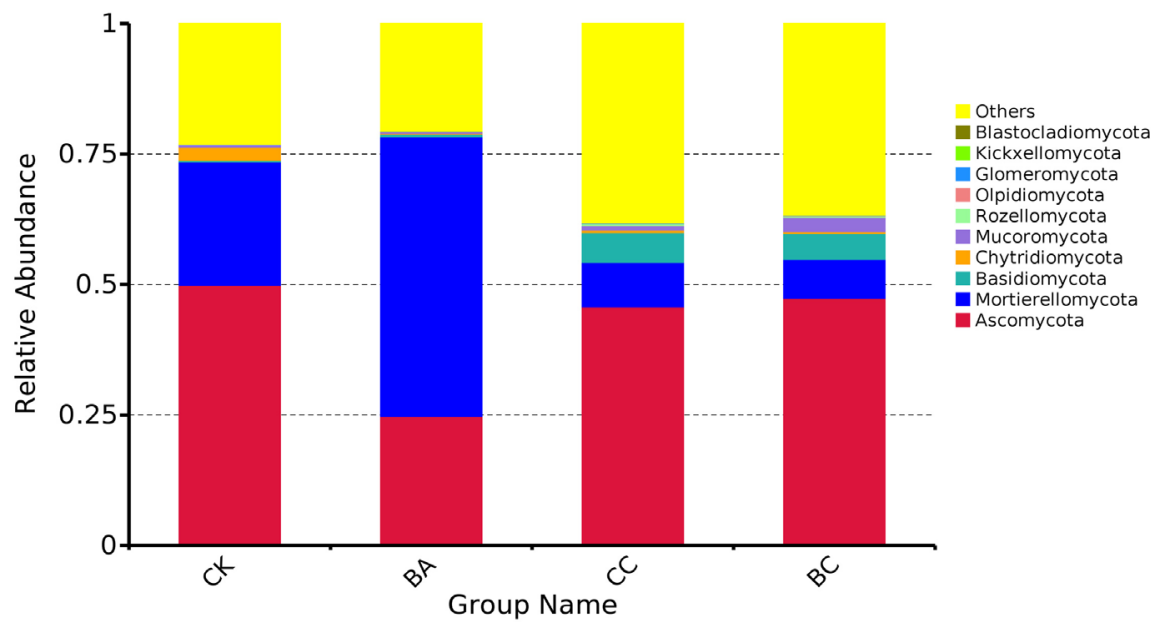

(b)

Figure 2. The relative abundance of bacterial phyla (a) and fungal phyla (b) in different treatments.

cyanamide affected the bacterial community structure.

The top 6 fungal phylum accounted for $68.79 \%-87.06 \%$ of the fungal community, and Ascomycota (36.40\% - 60.98\%), Mortierellomycota $(6.21 \%$ 48.60\%), Basidiomycota (0.25\% - 9.07\%), Mucoromycota (4.23\% - 3.62\%), Chytridiomycota $(0.25 \%-0.63 \%)$ and Rozellomycota $(0.04 \%-0.35 \%)$ were the 6 dominant fungal population (Figure 2(b)). The relative population of Basidiomycota in the CC and BC groups was found higher than those in the CK and BA groups. The relative population of Ascomycota in the CC and BC groups was observed higher than those in the BA group but lower than those in the $\mathrm{CK}$ group. Moreover, the relative population of Mortierellomycota in the CK group was significantly higher than that in CC and BC groups, but lower than those in the BA group. The findings demonstrate that the application of antagonistic bacteria combined with the calcium cyanamide influenced the composition of the fungal community.

The different distributions of the microbial community at the genus level be- 
tween the other treatment groups and CK group are illustrated in Figure S1. Terracidiphilus was one genus that found a significant difference between the $\mathrm{BA}$ and the CK groups (Figure S1(a)). There were 44 significantly different genera between the CC and the CK groups, and 42 significantly different genera between the $\mathrm{BC}$ and the $\mathrm{CK}$ group (Figure $\mathrm{S} 1(\mathrm{~b})$ and Figure $\mathrm{S} 1(\mathrm{c})$ ). The abundance of antagonistic bacteria Bacillus, Paenibacillus, Lysobacter, and Streptomyces in the $\mathrm{BC}$ and $\mathrm{CC}$ groups were higher than that in the CK group. while the abundance of nitrogen cycling bacterial Gaiella, Microvirga, and Nitrosospi$r a$ in the $\mathrm{BC}$ and $\mathrm{CC}$ groups were higher than that in the CK group. Moreover, the population of increasing plant health and growth bacteria Novosphingobium in $\mathrm{BC}$ and $\mathrm{CC}$ groups was higher than that in the CK group. The population of carbon cycling bacteria Steroidobacter and Solirubrobacter in BC and CC groups were both higher than that in the CK group, but the population of Chthonomonas in CC and BC groups was significantly lower than that in the $\mathrm{CK}$ group (Figure S1(b) and Figure S1(c)). At the genus level of fungal community, there was no significant difference of fungal proportions between the BA and CK groups, while Aspergillus, and Trichoderma as antagonistic fungal, were more abundant in the BC and CC groups than in the CK group (Figure S1(d) and Figure S1(e)).

For further exploring the distribution of the pathogenic and antagonistic microorganisms in different treatments, the abundances of these three types of microorganisms were calculated based on the absolute taxa abundance (Figure 3). Four pathogenic microorganisms were found in all the treatments, three of them were fungal pathogens, including Alternaria, Fusarium solani, and Fusarium oxysporum, and one was bacterial pathogens ( $R$. solanacearum). The population of $F$. oxysporum, F. solani, and $R$. solanacearum were higher $(p<0.05)$ in the $C K$ group than that in other treatments. Moreover, the population of pathogenic microorganisms in the BC group was the lowest of all treatments (Figure 3(a)). Twelve genera of antagonistic bacteria, including Streptomyces, Paenibacillus, Sphingomonas, Stenotrophomonas, Flavobacterium, Bacillus, Actinospica, Catenulispora, Haliangium and Lysobacter, and two genera of antagonistic fugal, including Aspergillus and Trichoderma were found in all treatments (Figure $3(\mathrm{~b})$ ). The population of most antagonistic microorganisms in the CK group was significantly lower $(p<0.05)$ than other treatments, excepting Flavobacterium, and Catenulispora. Therefore, the population of most antagonistic microorganisms was improved by loading antagonistic bacteria, calcium cyanamide, and combination of antagonistic bacteria and calcium cyanamide. Especially, Sphingomonas was significantly improved by loading antagonistic bacteria, and Streptomyces, Flavobacterium, Aspergillus, and Trichoderma were significantly improved by loading calcium cyanamide.

\subsection{The Correlation among the Microbial Community, Disease Index, and Soil Physicochemical Properties}

The Spearman correlation among the soil physicochemical, DI, and microbial 


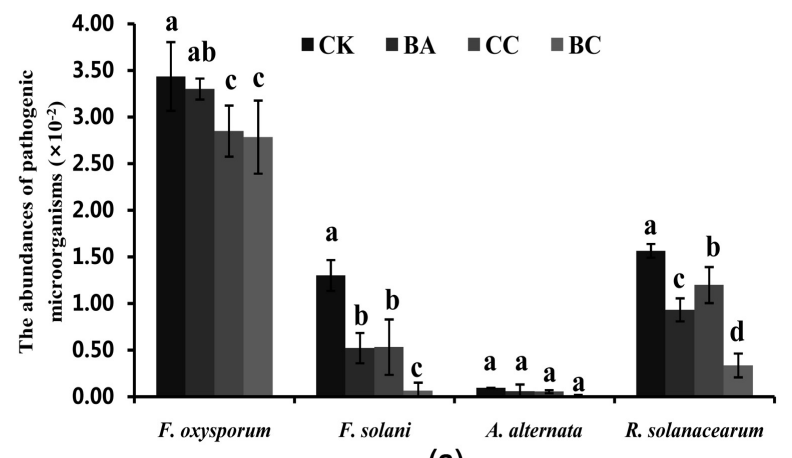

(a)

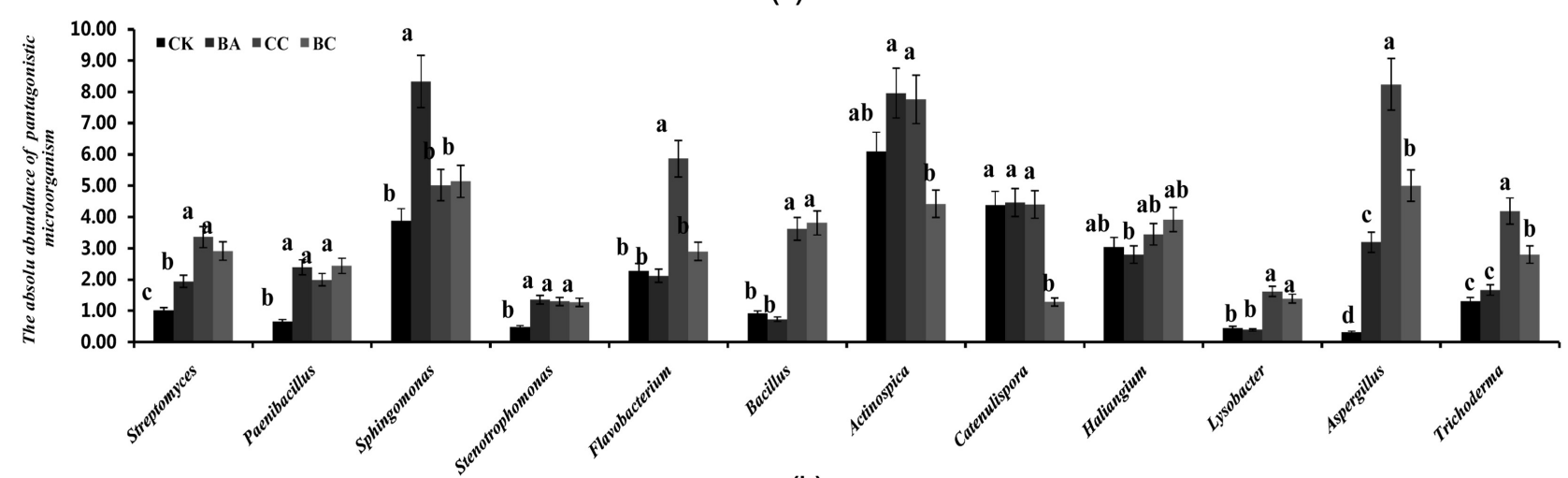

(b)

Figure 3. The absolute abundances of pathogenic microorganisms (a) and antagonistic microorganism (b) in different treatments. Values are means of SD $(\mathrm{n}=3)$. Bars with different letters are significantly different at $p<0.05$ by LSD test.

community were measured to evaluate association amid them (Table S3). The microbial richness and diversity were found in positive correlation with $\mathrm{pH}$, total $\mathrm{N}$, alkaline $\mathrm{N}$, available $\mathrm{K}$, exchangeable $\mathrm{Ca}$, and exchangeable $\mathrm{Mg}$. Additionally, the abundances of antagonistic microorganisms Streptomyces, Paenibacillus, Bacillus, Haliangium, Lysobacter, and Aspergillus were significantly correlated with soil physicochemical properties. Whereas pathogenic microorganisms $F$. solani, A. alternata, and $R$. solanacearum showed negatively correlated with soil physicochemical properties. According to the Spearman correlation, the microbial diversity, and the abundances of antagonistic microorganisms Streptomyces, Paenibacillus, Flavobacterium, Bacillus, Haliangium, Lysobacter, and Aspergillus showed a significantly negative relationship with the DI of tobacco bacterial wilt. However, pathogenic microorganisms F. solani, A. alternata, and $R$. solanacearum had a significantly positive relationship with the DI of tobacco bacterial wilt (Table S4). Besides, $\mathrm{pH}$, total $\mathrm{N}$, alkaline $\mathrm{N}$, available $\mathrm{K}$, exchangeable $\mathrm{Ca}$, and exchangeable $\mathrm{Mg}$ showed a significantly negative relationship with the DI of tobacco bacterial wilt, while organic matter and available $\mathrm{P}$ showed a significantly positive relationship with the DI of tobacco bacterial wilt (Table S5). These results indicated soil physicochemical properties had stronger effects on the microbial community. Furthermore, the microbial community structure affects the DI of bacterial wilt, especially the antagonistic microorganisms and pathogenic microorganisms. 


\section{Discussion}

The knowledge about the mechanism and action of integrated biological control of bacterial wilt will help out the restraining of soil-borne disease in agriculture. Current study amid to investigate the microbial community, the occurrence and DI of tobacco bacterial wilt, and physicochemical properties of rhizosphere soil. The single application of antagonistic bacteria, calcium cyanamide, and the combination of antagonistic bacteria and calcium cyanamide were confirmed to have an effect on the microbial community and successfully control the soil-borne disease. Additionally, the combination of antagonistic bacteria and calcium cyanamide showed to be more effective than the single application of antagonistic bacteria or calcium cyanamide, suggesting the integrated biological control method may be an applied approach for restraining tobacco bacterial wilt.

Biocontrol agents can increase the number of beneficial microorganisms and enhance the disease resistance of tobacco plants. They also work as bioorganic fertilizers because they help in the root growth and nutrient absorption. Control of bacterial wilt by integrated biological agents including antagonistic bacteria has been found effective in several reports [11] [15] [16]. Besides, soil amendment calcium cyanamide, a nitrogen fertilizer, can increase soil $\mathrm{pH}$, total $\mathrm{N}$, alkaline $\mathrm{N}$, and exchangeable $\mathrm{Ca}$. Furthermore, high soil $\mathrm{pH}$ is imperative for restraining bacterial wilt, higher $\mathrm{N}$ could enhance the competence of useful microorganisms against pathogens, and exchangeable $\mathrm{Ca}$ as fertilizer can increase Ca concentrations to lessen the severity of bacterial wilt [17] [18] [19]. Although antagonistic bacteria and calcium cyanamide were extensively used in the restraining of bacterial wilt, the mechanism of combined application of antagonistic bacteria and calcium cyanamide to control tobacco bacterial wilt is not known. In this study, the control efficacy of single application of antagonistic bacteria and calcium cyanamide was $46.43 \%$ and $51.92 \%$, respectively. However, the control efficacy of the combined application of antagonistic bacteria and calcium cyanamide reached $65.79 \%$. Besides, the $\mathrm{pH}$, total $\mathrm{N}$ alkaline $\mathrm{N}$, and exchangeable Ca were significantly higher for the combined application of antagonistic bacteria and calcium cyanamide than the single application of antagonistic bacteria. Moreover, Spearman correlation analysis showed $\mathrm{pH}$, total $\mathrm{N}$ alkaline $\mathrm{N}$, and exchangeable Ca were negatively correlated with microbial diversity, the soil-born pathogenic microorganisms, and DI of bacterial wilt, which were identical with previous investigations [20] [21]. Therefore, we suggest that the integrated measure reduces the occurrence of bacterial wilt by regulating soil physicochemical properties.

As is known, microbial communities are significant biological indicators for healthy soil. Additionally, soil microbial diversity, composition, and function have been considered to be important factors for maintaining long-term ecosystem balance and controlling plant soil-borne disease outbreaks [22] [23] [24]. Our findings of the current study show that Sobs, Chaol, and Shannon index of 
fungal and bacterial communities in the combined application of antagonistic bacteria and calcium cyanamide treatment group were remarkably higher than that in the single application of antagonistic bacteria and calcium cyanamide treatment groups. Additionally, the microbial diversity had a negative relationship with DI of bacterial wilt. This is similar to a previous report [24]. The results indicated that the integrated measure has a significantly positive effect on the diversity and richness of the microbial community of rhizospheric soil, thus reducing tobacco bacterial wilt. Moreover, it was also found that the integrated measure influences the structure of the microbial community. In the present investigation, compared with the control group, certain genera of microorganisms Gaiella, Microvirga, Nitrosospira, Steroidobacter, Solirubrobacter, and Novosphingobium were found in a larger population in rhizospheric soil subject to the combined application of antagonistic bacteria and calcium cyanamide. Previously reports showed that these genera have mostly beneficial effects on recycling nutrients in the soil, the genera Gaiella, Microvirga, and Nitrosospira played an important role in nitrogen cycling [9] [25]. Some genera of Chthonomonas, Steroidobacter, and Solirubrobacter were found to participate in organic carbon cycling in the soil [26]. Besides, Novosphingobium was reported to assist plant growth by increasing plant health and growth [27]. In the current study, these beneficial genera had a significantly negative relationship with DI of tobacco bacterial wilt. These genera can directly and effectively control soil-borne diseases by competing for nutrients, space, and induced systemic resistance [28]. Therefore, the integrated measure can affect soil microbial community and rebuild healthy soil microbial community structure to mitigate tobacco bacterial wilt.

The antagonistic bacterial species such as Streptomyces, Paenibacillus, Sphingomonas, Stenotrophomonas, Bacillus, Actinospica, Haliangium, and Lysobacter are well recognized as useful rhizosphere microorganisms and can mitigate many soil-borne diseases and promote plant growth and health [29] [30]. These were present abundantly in the combined application of antagonistic bacteria and calcium cyanamide treatment group. The antagonistic fungal Aspergillus and Trichoderma have been reported to interact directly with roots to produce bioactive substances that help in the growth of plants and fight against abiotic and biotic stress [31] [32]. The abundance of the above antagonistic fungal strains was higher in the single application of calcium cyanamide treatment group and the combination of antagonistic bacteria and calcium cyanamide treatment group. Furthermore, these antagonistic microbial showed a significantly negative relationship with the DI of tobacco bacterial wilt. Therefore, the proportion of antagonistic microbial was improved by the integrated measure treatment group, which is conducive to recruiting antagonistic adherents of the soil microbiome to shield tobacco plants from disease. Studies have reported that diverse microbial communities tend to be less vulnerable to pathogens attack than a simpler microbial community [33]. Our study showed that the abundances of pathogens $R$. solanacearum, $F$. oxysporum, and $F$. solani were signifi- 
cantly lower in the combined application of antagonistic bacteria and calcium cyanamide treatment group than the control group. Besides, these pathogens had significantly correlated with soil physicochemical properties and positive correlation with the DI of bacterial wilt. Consistent with the above findings, the combination of antagonistic bacteria and calcium cyanamide treatment group can control tobacco bacterial wilt through increasing the microbial community diversity and resist the invasion of pathogens.

\section{Materials and Methods}

\subsection{Field Experiment}

The field trial was performed from March to September 2018 at a tobacco field in Xuanen County $\left(109^{\circ} 26^{\prime} 20^{\prime \prime} \mathrm{E}, 29^{\circ} 59^{\prime} 55^{\prime \prime} \mathrm{N}\right)$, Hubei province, China. The experiment field was continuous cropping for 15 years, and the bacterial wilt was serious. Tobacco seedlings (Yunyan87) were grown in the greenhouse for around 60 days earlier being moved to replate in the trail field. The trial field was divided into four blocks according to the experimental design, each $90 \mathrm{~m}^{2}$ in size, representing four treatments: 1) the control group (CK); 2) the BA group applied with Bacillus amyloliquefaciens ZM9 [34]. A dilute solution of ZM9 cultures was prepared in water-bearing $1.0 \times 10^{7} \mathrm{CFU} / \mathrm{mL}$ cell concentration and then watered into the tobacco root $(100 \mathrm{~mL}$ per plant) after tobacco transplanting; 3) the CC group was applied with $22.5 \mathrm{~g} / \mathrm{m}^{2}$ of calcium cyanamide to the soil at $20 \mathrm{~d}$ pre-transplantation (CC); and 4) the $\mathrm{BC}$ group was treated with calcium cyanamide and Bacillus amyloliquefaciens ZM9 as CC and BA. There were 60 tobacco plants in each section, every plant was apart of $0.55 \mathrm{~m}$ in a row, and each row was at a distance of $1.2 \mathrm{~m}$.

\subsection{Rhizosphere Soil Samples and Basic Parameter Calculation}

Rhizosphere soil samples were collected at $68 \mathrm{~d}$ post-transplantation by the five-spot-sampling method and transported to the lab, then stored at $-80^{\circ} \mathrm{C}$ for microbial community analysis, and at $25^{\circ} \mathrm{C}$ for physicochemical properties analysis. To study the soil characteristics and available nutrients, collected soil specimens were air-dried and mechanically crushed into less than $2 \mathrm{~mm}$ mesh sized powder. Exchangeable magnesium $(\mathrm{Mg})$ and calcium $(\mathrm{Ca})$, available potassium $(\mathrm{K})$, available phosphorus $(\mathrm{P})$, alkaline nitrogen $(\mathrm{N})$, total nitrogen $(\mathrm{N})$, organic matter, and $\mathrm{pH}$ were determined by atomic absorption spectrophotometry, flame spectrophotometer, sodium bicarbonate method, alkali solution diffusion method, Kjeldahl method, potassium dichromate volumetric method, and potentiometric method, respectively [35].

\subsection{Incidence and Disease Index Calculation}

The symptoms of tobacco bacterial wilt of all 60 plants in each section were monitored at $15 \mathrm{~d}$ post-transplantation. The severity scale from 0 to 9 was used as reported in an earlier study [14]. Disease incidence (I) and disease index (DI) 
were measured using the given formula.

$\mathrm{I}=\mathrm{DI}=[\Sigma$ (the number of bacterial wilt crops in this index $\times$ severity scale)/(total number of crops inspected $\times$ the highest severity scale) $] \times 100$.

Similarly, the control efficacy of BA, CC, and BC was also calculated based on DI.

Control efficacy $=[($ Control DI - Treatment DI $) /$ Control DI $] \times 100 \%$.

\subsection{Extraction and Purification of Soil Microbial DNA}

For microbial DNA extraction, $0.5 \mathrm{~g}$ soil was weighed precisely from each sample stocked for genome analysis. The FastDNA Spin Kit (MP Biomedicals, USA) was used to extract the soil microbial genomic DNA following the prescribed procedures and specifications. The $1 \%$ agarose gel electrophoresis was employed to measure the integrity of DNA samples. Subsequently, the Nanodrop was used to evaluate the purity and concentration of DNA.

\subsection{PCR Amplification and Sequencing}

The microbial DNA isolated from the rhizosphere soil samples was subjected to use as a template for replication of ITS rRNA and 16S rRNA genes. The DNA samples were diluted to $1 \mathrm{ng} \cdot \mu \mathrm{L}^{-1}$ with millipore water. The primers $806 \mathrm{R}$

(5'-GGACTACHVGGGTWTCTAAT-3') and 515F

(5'-GTGCCAGCMGCCGCGGTAA-3') [16] were used to copy the V4 regions of the 16S rRNA gene, while the primers ITS2-2043R

(5'-GCTGCGTTCTTCATCGATGC-3') and ITS5-1737F

(5'-GGAAGTAAAAGTCGTAACAAGG-3') [36] were used to copy the ITS1 regions of ITS rRNA gene. The Illumina HiSeq platform was used to conduct all PCR reactions and sequencing libraries were constructed with the use of the TruSeq ${ }^{\circledR}$ DNA (Illumina, USA) following the prescribed procedures and approvals. After that, the quality of the library was assessed using Bioanalyzer 2100 system and the Qubit@2.0 Fluorometer. Finally, the Illumina HiSeq 2500 platform was used to sequence the DNA library preparation and 250 bp paired-end reads were gained.

\subsection{Sequence Data Analysis}

The FLASH (V1.2.7) software was employed to merge the paired-end reads and assigned to the corresponding samples using the unique barcodes. The QIIME (V1.7.0) software was used at specific filtering parameters to filter the raw tags and gain the fine clean tags. The Uparse (V7.0.1001) software was used for the sequence analysis and sequences with $\geq 97 \%$ similarity were allocated to the same OTUs. Each distinctive sequence was screened for further taxonomic information annotation. Four indices, OTUs number, observed species (Sobs), Chaol, and Shannon index were measured to evaluate diversity and fertility of soil microbial community. The Student's t-test (T-test) was applied to analyze the differences of microbial proportions at the genus level among treatments. The 
QIIME software and R software (V2.15.3) were used to measure all indices and displayed, respectively.

\subsection{Statistical Analysis}

The SPSS version 18.0 (IBM, USA) and Microsoft Excel 2007 were employed to analyze the data. The significant difference amid treatments was measured with a one-way analysis of variance (ANOVA) and the least significant difference (LSD) test $(p<0.05)$. Correlation analysis was conducted by spearman (2tailed).

\section{Conclusion}

The findings of the current study suggest that the integrated measure can regulate soil physicochemical properties, and effectively reduce the incidence of tobacco bacterial wilt, thus obviously increase the diversity and richness of soil microorganisms. It can further effectively resist the invasion of pathogens, and promote the transformation of diseased soil ecosystem into healthy and sustainable development through prevention and control of tobacco bacterial wilt.

\section{Author Contributions}

Yong Yang and Yanyan Li initiated and designed the research. Xiaoqiong Yang, Chunli Li, Lin Wang and Ji Feng performed the experiments and collected the data. Yun $\mathrm{Hu}$ analyzed the data and wrote the manuscript. Yong Yang and Shouwen Chen revised the manuscript. All authors reviewed and approved the final manuscript.

\section{Funding}

This work was funded by the Science and Technology Research Project of Education Department of Hubei Province (D20201003).

\section{Conflicts of Interest}

The authors declare no conflict of interest.

\section{References}

[1] Denny, T.P. (2000) Ralstonia Solanacearum-A Plant Pathogen in Touch with Its Host. Trends in Microbiology, 8, 486-489. https://doi.org/10.1016/S0966-842X(00)01860-6

[2] Yuliar, Nion, Y.A. and Toyota, K. (2015) Recent Trends in Control Methods for Bacterial Wilt Diseases Caused by Ralstonia solanacearum. Microbes and Environments, 30, ME14144.

[3] Hayward, A.J. (1991) Biology and Epidemiology of Bacterial Wilt Caused by Pseudomonas solanacearum. Annual Review of Phytopathology, 29, 65-87. https://doi.org/10.1146/annurev.py.29.090191.000433

[4] Gamliel, A., Austerweil, M. and Kritzman, G.J. (2000) Non-Chemical Approach to Soilborne Pest Management-Organic Amendments. Crop protection, 19, 847-853. 
https://doi.org/10.1016/S0261-2194(00)00112-5

[5] Hayward, A.J. (1964) Characteristics of Pseudomonas Solanacearum. Journal of Applied Bacteriology, 27, 265-277. https://doi.org/10.1111/j.1365-2672.1964.tb04912.x

[6] Liu, Y., Shi, J., Feng, Y., Yang, X., Li, X. and Shen, Q.R. (2013) Tobacco Bacterial Wilt Can Be Biologically Controlled by the Application of Antagonistic Strains in Combination with Organic Fertilizer. Biology and Fertility of Soils, 49, 447-464. https://doi.org/10.1007/s00374-012-0740-Z

[7] Niu, J., Chao, J., Xiao, Y., Chen, W., Zhang, C., Liu, X., Rang, Z., Yin, H. and Dai, L.J. (2017) Insight into the Effects of Different Cropping Systems on Soil Bacterial Community and Tobacco Bacterial Wilt Rate. Journal of Basic Microbiology, 57, 3-11. https://doi.org/10.1002/jobm.201600222

[8] Yang, H., Li, J., Xiao, Y., Gu, Y., Liu, H., Liang, Y., Liu, X., Hu, J., Meng, D. and Yin, H.J. (2017) An Integrated Insight into the Relationship between Soil Microbial Community and Tobacco Bacterial Wilt Disease. Frontiers in Microbiology, 8, 2179. https://doi.org/10.3389/fmicb.2017.02179

[9] Chen, W., Teng, Y., Li, Z., Liu, W., Ren, W., Luo, Y. and Christie, P.J. (2018) Mechanisms by Which Organic Fertilizer and Effective Microbes Mitigate Peanut Continuous Cropping Yield Constraints in a Red Soil of South China. Applied Soil Ecology, 128, 23-34. https://doi.org/10.1016/j.apsoil.2018.03.018

[10] Yuan, Y., Feng, H., Wang, L., Li, Z., Shi, Y., Zhao, L., Feng, Z. and Zhu, H.Q. (2017) Potential of Endophytic Fungi Isolated from Cotton Roots for Biological Control against Verticillium Wilt Disease. PLoS ONE, 12, e0170557.

https://doi.org/10.1371/journal.pone.0170557

[11] Yuan, S., Li, M., Fang, Z., Liu, Y., Shi, W., Pan, B., Wu, K., Shi, J., Shen, B. and Shen, Q.J. (2016) Biological Control of Tobacco Bacterial Wilt Using Trichoderma harzianum Amended Bioorganic Fertilizer and the Arbuscular Mycorrhizal Fungi Glomus mosseae. Biological Control, 92, 164-171. https://doi.org/10.1016/j.biocontrol.2015.10.013

[12] Alsaad, K.O., Hajeer, A.H., Al Balwi, M., Al Moaiqel, M., Al Oudah, N., Al Ajlan, A., AlJohani, S., Alsolamy, S., Gmati, G.E., Balkhy, H., et al. (2018) Histopathology of Middle East Respiratory Syndrome Coronovirus (MERS-CoV) InfectionClinicopathological and Ultrastructural Study. Histopathology, 72, 516-524. https://doi.org/10.1111/his.13379

[13] Messiha, N., Van Bruggen, A., Franz, E., Janse, J., Schoeman-Weerdesteijn, M., Termorshuizen, A. and Van Diepeningen, A.J.A.S.E. (2009) Effects of Soil Type, Management Type and Soil Amendments on the Survival of the Potato Brown Rot Bacterium Ralstonia solanacearum. Applied Soil Ecology, 43, 206-215. https://doi.org/10.1016/j.apsoil.2009.07.008

[14] Zhang, C., Lin, Y., Tian, X., Xu, Q., Chen, Z. and Lin, W. (2017) Tobacco Bacterial Wilt Suppression with Biochar Soil Addition Associates to Improved Soil Physiochemical Properties and Increased Rhizosphere Bacteria Abundance. Applied Soil Ecology, 112, 90-96. https://doi.org/10.1016/j.apsoil.2016.12.005

[15] Yuan, S., Wang, L., Wu, K., Shi, J., Wang, M., Yang, X., Shen, Q. and Shen, B. (2014) Evaluation of Bacillus-Fortified Organic Fertilizer for Controlling Tobacco Bacterial Wilt in Greenhouse and Field Experiments. Applied Soil Ecology, 75, 86-94. https://doi.org/10.1016/j.apsoil.2013.11.004

[16] Wu, B., Wang, X., Yang, L., Yang, H., Zeng, H., Qiu, Y., Wang, C., et al. (2016) Effects of Bacillus amyloliquefaciens ZM9 on Bacterial Wilt and Rhizosphere 
Microbial Communities of Tobacco. Applied Soil Ecology, 103, 1-12. https://doi.org/10.1016/j.apsoil.2016.03.002

[17] Choi, H.-W., Chung, I.-M., Sin, M.H., Kim, Y.S., Sim, J.-B., Kim, J.-W., Kim, K.D. and Chun, S.-C. (2007) The Effect of Spent Mushroom Sawdust Compost Mixes, Calcium Cyanamide and Solarization on Basal Stem Rot of the Cactus Hylocereus trigonus Caused by Fusarium oxysporum. Crop Protection, 26, 162-168. https://doi.org/10.1016/j.cropro.2006.04.017

[18] Shi, K., Wang, L., Zhou, Y.-H., Yu, Y.-L. and Yu, J.-Q. (2009) Effects of Calcium Cyanamide on Soil Microbial Communities and Fusarium oxysporum f. sp. Cucumberinum. Chemosphere, 75, 872-877. https://doi.org/10.1016/j.chemosphere.2009.01.054

[19] He, K., Yang, S.-Y., Li, H., Wang, H. and Li, Z.-L. (2014) Effects of Calcium Carbonate on the Survival of Ralstonia solanacearum in Soil and Control of Tobacco Bacterial Wilt. European Journal of Plant Pathology, 140, 665-675. https://doi.org/10.1007/s10658-014-0496-4

[20] Yin, S., Dong, Y., Xu, Y., Huang, Q. and Shen, Q.R. (2011) Upland Rice Seedling Wilt and Microbial Biomass and Enzyme Activities of Compost-Treated Soils. Biology and Fertility of Soils, 47, 303-313. https://doi.org/10.1007/s00374-010-0537-x

[21] Wang, Q., Ma, Y., Yang, H. and Chang, Z. (2014) Effect of Biofumigation and Chemical Fumigation on Soil Microbial Community Structure and Control of Pepper Phytophthora Blight. World Journal of Microbiology and Biotechnology, 30, 507-518. https://doi.org/10.1007/s11274-013-1462-6

[22] Kennedy, A.C. and Smith, K.J.P. (1995) Microbial Diversity and the Sustainability of Agricultural Soils. Plant and Soil, 170, 75-86. https://doi.org/10.1007/BF02183056

[23] Zhou, X. and Wu, F. (2012) Dynamics of the Diversity of Fungal and Fusarium Communities during Continuous Cropping of Cucumber in the Greenhouse. FEMS Microbiology Ecology, 80, 469-478. https://doi.org/10.1111/j.1574-6941.2012.01312.x

[24] Wang, R., Zhang, H., Sun, L., Qi, G., Chen, S. and Zhao, X.Y. (2017) Microbial Community Composition Is Related to Soil Biological and Chemical Properties and Bacterial Wilt Outbreak. Scientific Reports, 7, Article No. 343.

https://doi.org/10.1038/s41598-017-00472-6

[25] Rodrigues Coelho, M.R., De Vos, M., Carneiro, N.P., Marriel, I.E., Paiva, E. and Seldin, L. (2008) Diversity of nifH Gene Pools in the Rhizosphere of Two Cultivars of Sorghum (Sorghum bicolor) Treated with Contrasting Levels of Nitrogen Fertilizer. FEMS Microbiology Letters, 279, 15-22.

https://doi.org/10.1111/j.1574-6968.2007.00975.x

[26] Lee, K.C., Morgan, X.C., Dunfield, P.F., Tamas, I., McDonald, I.R. and Stott, M.B. (2014) Genomic Analysis of Chthonomonas Calidirosea, the First Sequenced Isolate of the Phylum Armatimonadetes. The ISME Journal, 8, 1522-1533. https://doi.org/10.1038/ismej.2013.251

[27] Rangjaroen, C., Sungthong, R., Rerkasem, B., Teaumroong, N., Noisangiam, R. and Lumyong, S. (2017) Environments. Untapped Endophytic Colonization and Plant Growth-Promoting Potential of the Genus Novosphingobium to Optimize Rice Cultivation. Microbes and Environments, 32, 84-87.

https://doi.org/10.1264/jsme2.ME16112

[28] Agrios, G.N. (2005) Plant Pathology. Elsevier, Burlington, 79-103.

[29] Badri, D.V., Weir, T.L., van der Lelie, D. and Vivanco, J.M. (2009) Rhizosphere 
Chemical Dialogues: Plant-Microbe Interactions. Current Opinion in Biotechnology, 20, 642-650. https://doi.org/10.1016/j.copbio.2009.09.014

[30] Raza, W., Ling, N., Yang, L., Huang, Q. and Shen, Q. (2016) Response of Tomato Wilt Pathogen Ralstonia Solanacearum to the Volatile Organic Compounds Produced by a Biocontrol Strain Bacillus amyloliquefaciens SQR-9. Scientific Reports, 6, Article No. 24856. https://doi.org/10.1038/srep24856

[31] Pattee, H.E. (1969) Production of Aflatoxins by Aspergillus flavus Cultured on Flue-Cured Tobacco. Applied Microbiology, 18, 952-953. https://doi.org/10.1128/AM.18.5.952-953.1969

[32] Silva, R.N., Monteiro, V.N., Steindorff, A.S., Gomes, E.V., Noronha, E.F. and Ulhoa, C.J. (2019) Trichoderma/Pathogen/Plant Interaction in Pre-Harvest Food Security. Fungal Biology, 123, 565-583. https://doi.org/10.1016/j.funbio.2019.06.010

[33] van Elsas, J.D., Chiurazzi, M., Mallon, C.A., Elhottovā, D., Krištůfek, V. and Salles, J.F. (2012) Microbial Diversity Determines the Invasion of Soil by a Bacterial Pathogen. Proceedings of the National Academy of Sciences, 109, 1159-1164. https://doi.org/10.1073/pnas.1109326109

[34] Yao, D., Ji, Z., Wang, C., Qi, G., Zhang, L., Ma, X. and Chen, S. (2012) Co-Producing Iturin A and Poly- $\gamma$-Glutamic Acid from Rapeseed Meal Under Solid State Fermentation by the Newly Isolated Bacillus subtilis Strain 3-10. World Journal of Microbiology and Biotechnology, 28, 985-991. https://doi.org/10.1007/s11274-011-0896-y

[35] Martinez, C., Michaud, M., Belanger, R. and Tweddell, R.J. (2002) Biochemistry. Identification of Soils Suppressive against Helminthosporium solani, the Causal Agent of Potato Silver Scurf. Soil Biology and Biochemistry, 34, 1861-1868. https://doi.org/10.1016/S0038-0717(02)00199-2

[36] Li, Y.Y., Feng, J., Zheng, L., Huang, J.B., Yang, Y. and Li, X.H. (2020) Intercropping with Marigold Promotes Soil Health and Microbial Structure to Assist in Mitigating Tobacco Bacterial Wilt. Journal of Plant Pathology, 102, 731-742. https://doi.org/10.1007/s42161-020-00490-w 


\section{Supplementary Materials}

$\square \mathrm{CK} \square$ BA

$95 \%$ confidence intervals

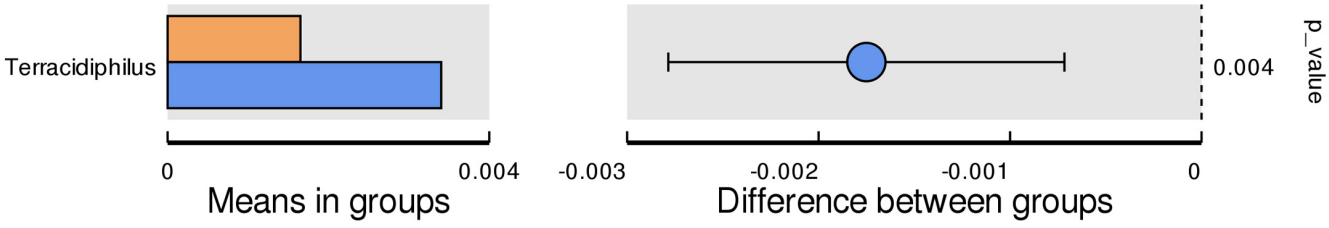

(a)
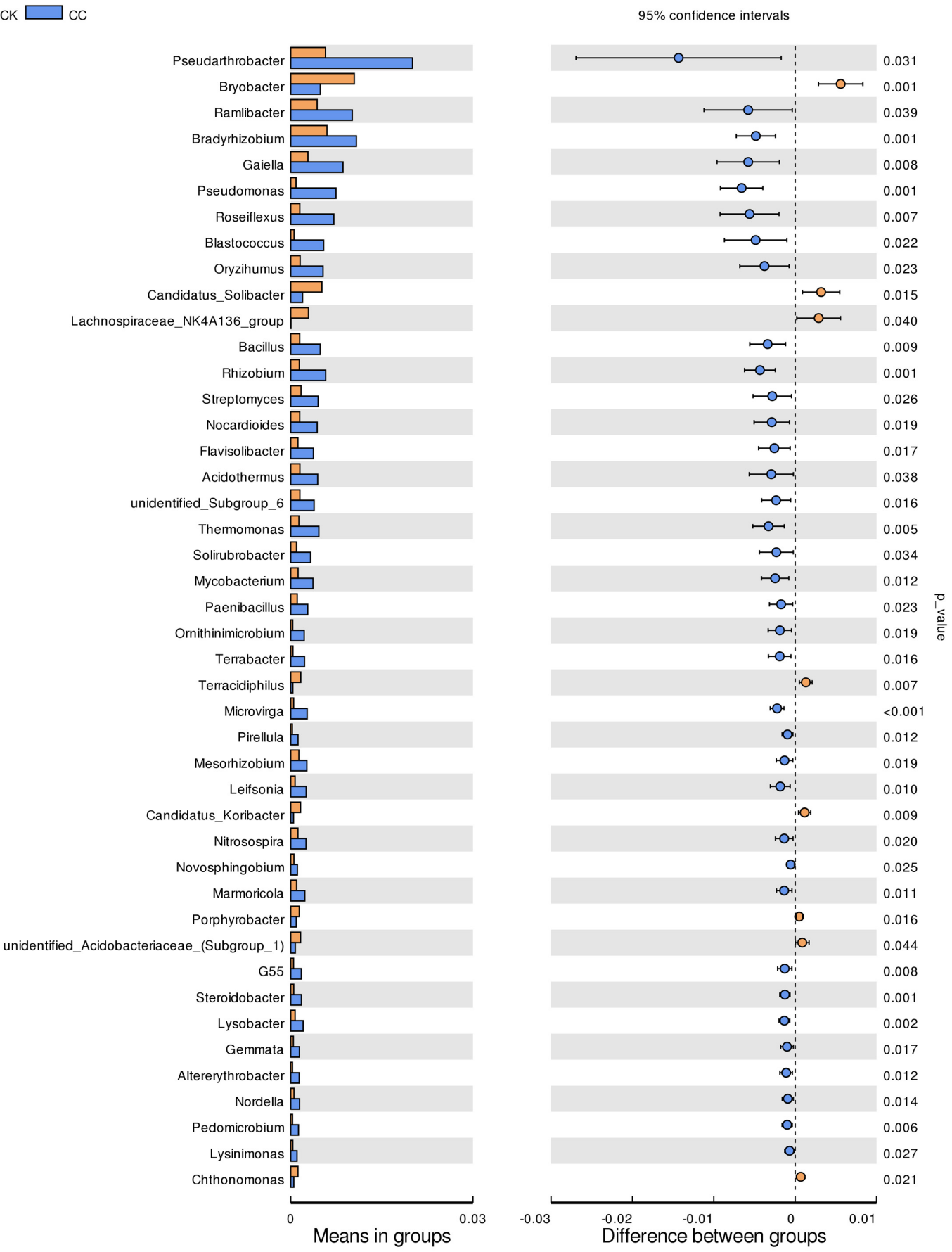

(b) 

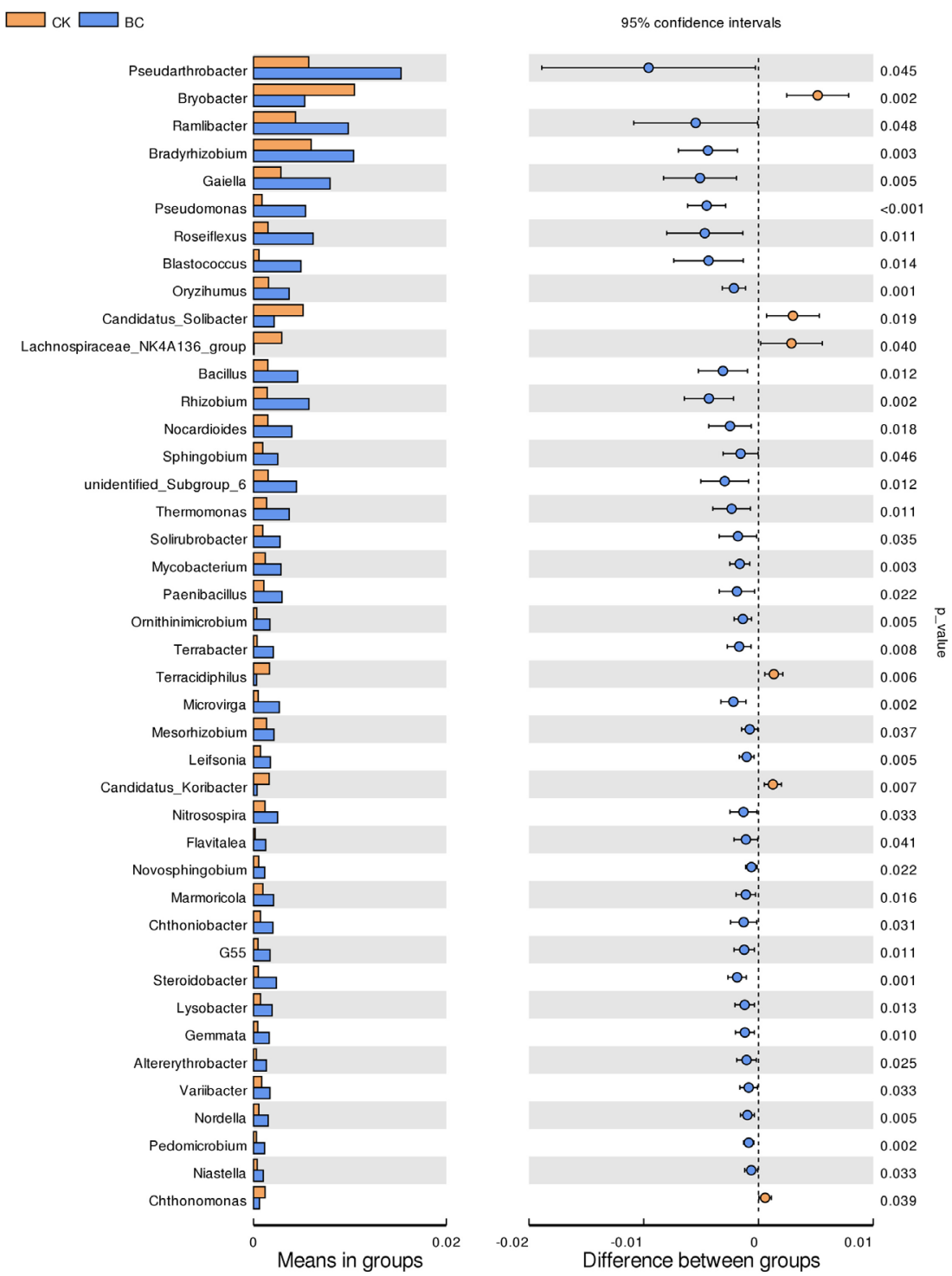

(c)

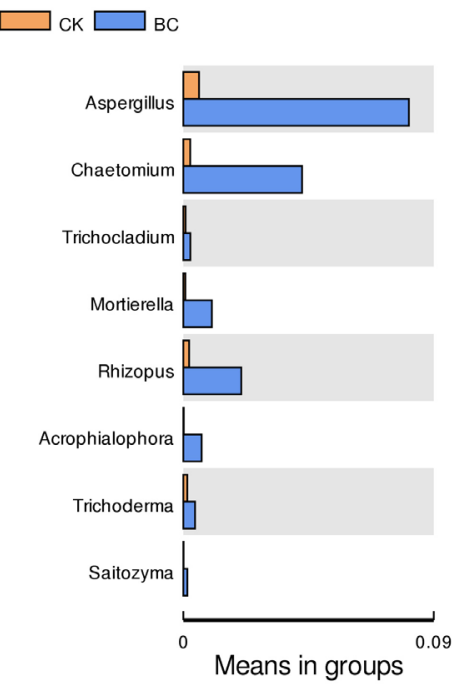

$95 \%$ confidence intervals

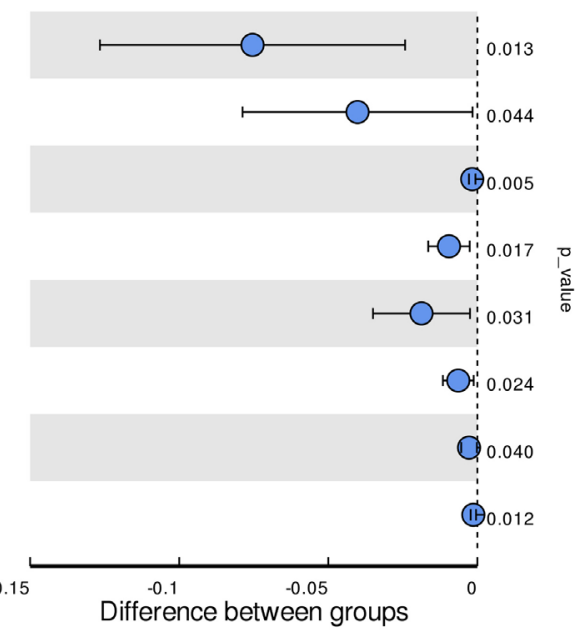

(d) 

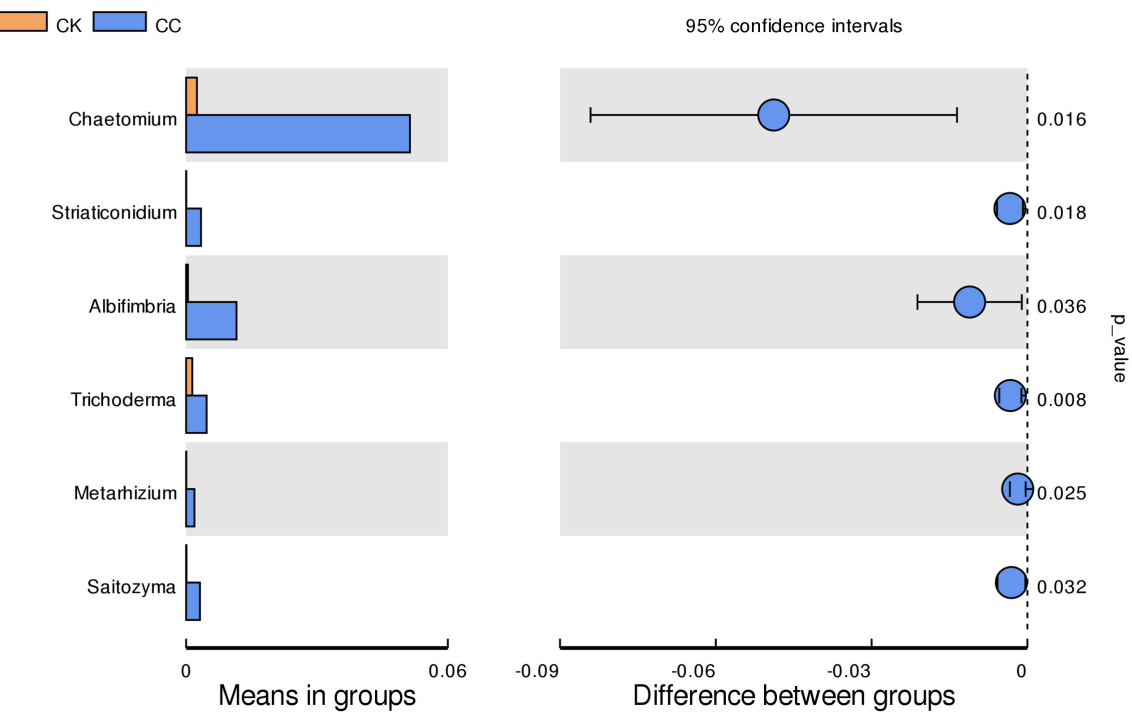

(e)

Figure S1. Differential analysis of bacterial proportions at the genus level between CK and BA (a), CK, and CC (b), CK, and BC (c). Differential analysis of fungal proportions at the genus level between CK and BC (d), CK, and CC (e). The abundances of different genera were analyzed by the T-test.

Table S1. Soil physiochemical properties in different treatments.

\begin{tabular}{|c|c|c|c|c|}
\hline \multirow{2}{*}{ Chemical properties } & \multicolumn{4}{|c|}{ Treatment } \\
\hline & CK & BA & $\mathrm{CC}$ & $\mathrm{BC}$ \\
\hline $\mathrm{pH}$ & $5.09 \pm 0.09 \mathrm{~d}$ & $6.05 \pm 0.22 c$ & $7.10 \pm 0.12 b$ & $7.40 \pm 0.23 a$ \\
\hline organic matter (\%) & $3.22 \pm 0.07 a$ & $2.67 \pm 0.14 b$ & $2.32 \pm 0.07 c$ & $2.07 \pm 0.05 d$ \\
\hline total N (\%) & $0.13 \pm 0.01 b$ & $0.14 \pm 0.01 b$ & $0.17 \pm 0.01 \mathrm{a}$ & $0.18 \pm 0.01 \mathrm{a}$ \\
\hline alkaline $\mathrm{N}$ (mg/kg) & $107.75 \pm 2.45 \mathrm{~d}$ & $126.17 \pm 3.37 \mathrm{c}$ & $140.76 \pm 6.07 b$ & $163.09 \pm 5.37 \mathrm{a}$ \\
\hline available $\mathrm{K}$ (mg/kg) & $439.35 \pm 22.64 b$ & $575.91 \pm 16.37 a$ & $593.13 \pm 37.25 a$ & $610.89 \pm 35.57 \mathrm{a}$ \\
\hline exchangeable $\mathrm{Ca}(\mathrm{mg} / \mathrm{kg})$ & $1302.75 \pm 90.23 c$ & $1525.01 \pm 50.69 b$ & $2325.01 \pm 122.06 \mathrm{a}$ & $2450.71 \pm 141.58 \mathrm{a}$ \\
\hline exchangeable Mg (mg/kg) & $96.20 \pm 1.20 \mathrm{~d}$ & $111.45 \pm 5.71 c$ & $132.57 \pm 6.59 b$ & $152.00 \pm 10.42 \mathrm{a}$ \\
\hline
\end{tabular}

Values are means of SD $(n=3)$. The different letters in a row indicate significant differences as determined by the LSD test $(p<0.05)$.

Table S2. Characteristics of effective tags from samples of different treatments.

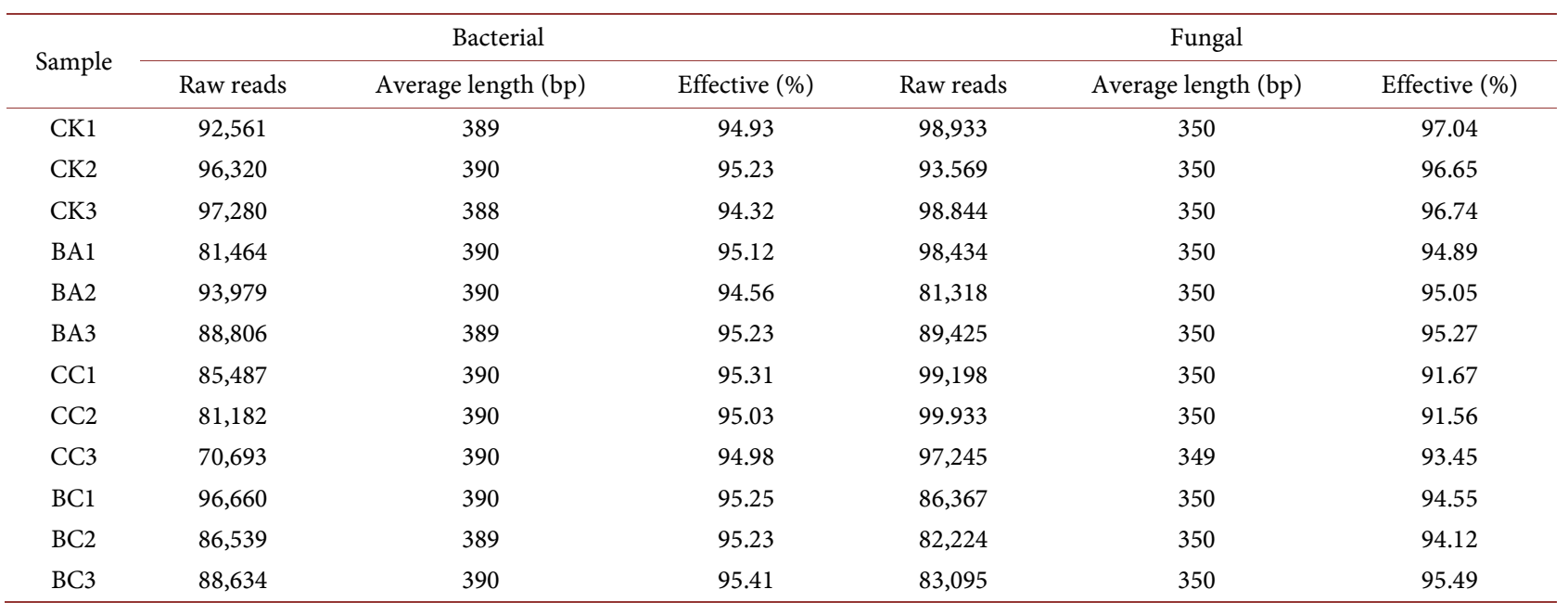


Table S3. Spearman correlation analysis between microbial community and soil physicochemical properties.

\begin{tabular}{|c|c|c|c|c|c|c|c|c|c|}
\hline & & $\mathrm{pH}$ & $\begin{array}{l}\text { organic } \\
\text { matter }\end{array}$ & $\begin{array}{l}\text { total } \\
\mathrm{N}\end{array}$ & $\begin{array}{c}\text { alkaline } \\
\mathrm{N}\end{array}$ & $\begin{array}{c}\text { available } \\
\text { P }\end{array}$ & $\begin{array}{c}\text { available } \\
\mathrm{K}\end{array}$ & $\begin{array}{c}\text { exchangeable } \\
\mathrm{Ca}\end{array}$ & $\begin{array}{c}\text { exchangeable } \\
\mathrm{Mg}\end{array}$ \\
\hline \multirow{2}{*}{ Bacteria } & Sobs & $0.958^{* *}$ & $-0.902^{* *}$ & $0.787^{\star *}$ & $0.930^{* *}$ & $-0.993^{\star *}$ & 0.573 & $0.776^{* *}$ & $0.965^{* *}$ \\
\hline & chao1 & $0.867^{* *}$ & $-0.895^{\star *}$ & $0.714^{* *}$ & $0.895^{* *}$ & $-0.874^{\star *}$ & $0.664^{*}$ & $0.895^{* *}$ & $0.874^{* *}$ \\
\hline 0.8 & shannon & $0.937^{* *}$ & $-0.923^{\star *}$ & $0.808^{* *}$ & $0.951^{* *}$ & $-0.993^{\star *}$ & 0.573 & $0.797^{* *}$ & $0.944^{* *}$ \\
\hline \multirow{3}{*}{ Fungal } & Sobs & $0.923^{* *}$ & $-0.916^{* *}$ & $0.879^{* *}$ & $0.930^{* *}$ & $-0.944^{\star *}$ & $0.636^{*}$ & $0.783^{* *}$ & $0.958^{* *}$ \\
\hline & chaol & $0.671^{*}$ & $-0.699^{\star}$ & $0.763^{\star *}$ & $0.741^{\star *}$ & $-0.762^{\star \star}$ & 0.476 & $0.608^{*}$ & $0.727^{\star *}$ \\
\hline & shannon & $0.937^{* *}$ & $-0.930^{* *}$ & $0.872^{* *}$ & $0.923^{* *}$ & $-0.930^{\star *}$ & $0.692^{*}$ & $0.818^{* *}$ & $0.986^{* *}$ \\
\hline \multirow{12}{*}{ Antagonistic } & Streptomyces & $0.832^{* *}$ & $-0.797^{\star *}$ & $0.749^{* *}$ & $0.790^{* *}$ & $-0.776^{* *}$ & 0.469 & $0.685^{\star}$ & $0.769^{* *}$ \\
\hline & Paenibacillus & $0.804^{\star \star}$ & $-0.793^{\star *}$ & $0.716^{\star *}$ & $0.867^{\star *}$ & $-0.800^{\star *}$ & 0.502 & $0.772^{\star *}$ & $0.705^{\star}$ \\
\hline & Sphingomonas & 0.301 & -0.287 & 0.274 & 0.371 & -0.287 & 0.196 & 0.224 & 0.315 \\
\hline & Stenotrophomonas & 0.140 & -0.224 & 0.190 & 0.252 & -0.133 & 0.252 & 0.210 & 0.182 \\
\hline & Flavobacterium & 0.494 & -0.560 & $0.606^{*}$ & 0.564 & -0.483 & 0.511 & $0.637^{*}$ & 0.571 \\
\hline & Bacillus & $0.727^{\star *}$ & $-0.776^{\star *}$ & $0.724^{* *}$ & $0.776^{* *}$ & $-0.671^{\star}$ & 0.490 & $0.818^{* *}$ & $0.650^{*}$ \\
\hline & Actinospica & -0.322 & 0.427 & -0.524 & -0.434 & 0.371 & 0.147 & -0.035 & -0.350 \\
\hline & Catenulispora & -0.238 & 0.350 & -0.513 & -0.364 & 0.224 & 0.210 & 0.105 & 0.245 \\
\hline & Haliangium & $0.762^{\star *}$ & $-0.818^{\star *}$ & $0.872^{\star *}$ & $0.888^{\star *}$ & $-0.790^{\star *}$ & $0.580^{*}$ & $0.727^{\star \star}$ & $0.769^{* *}$ \\
\hline & Lysobacter & $0.748^{\star *}$ & $-0.734^{\star *}$ & $0.777^{* *}$ & $0.741^{* *}$ & $-0.720^{* *}$ & 0.538 & $0.734^{* *}$ & $0.797^{* *}$ \\
\hline & Aspergillus & $0.706^{*}$ & $-0.643^{*}$ & 0.267 & 0.545 & $-0.643^{\star}$ & 0.573 & $0.720^{* *}$ & $0.713^{* *}$ \\
\hline & Trichoderma & 0.021 & -0.252 & 0.313 & 0.252 & -0.077 & 0.455 & 0.259 & 0.112 \\
\hline \multirow{4}{*}{ Pathogenic } & F. oxysporum & -0.369 & 0.341 & -0.182 & -0.411 & 0.538 & -0.264 & -0.404 & -0.432 \\
\hline & F. solani & $-0.735^{\star *}$ & $0.819^{* *}$ & $-0.687^{\star}$ & $-0.749^{* *}$ & $0.699^{*}$ & -0.320 & -0.573 & $0.692^{*}$ \\
\hline & A. alternata & $-0.798^{\star *}$ & $0.685^{\star}$ & -0.504 & $-0.770^{\star *}$ & $0.805^{\star *}$ & -0.482 & -0.552 & $-0.721^{\star \star}$ \\
\hline & R. solanacearum & $-0.847^{\star \star}$ & $0.896^{\star *}$ & $-0.793^{\star \star}$ & $-0.875^{\star *}$ & $0.798^{\star *}$ & -0.531 & $-0.685^{\star}$ & $-0.819^{\star \star}$ \\
\hline
\end{tabular}

${ }^{*}$ and ${ }^{* *}$ indicate correlation is significant at $p<0.05$ and $p<0.01$.

Table S4. Spearman correlation analysis between pathogenic, antagonistic microorganisms, microbial diversity and disease index of tobacco bacterial wilt.

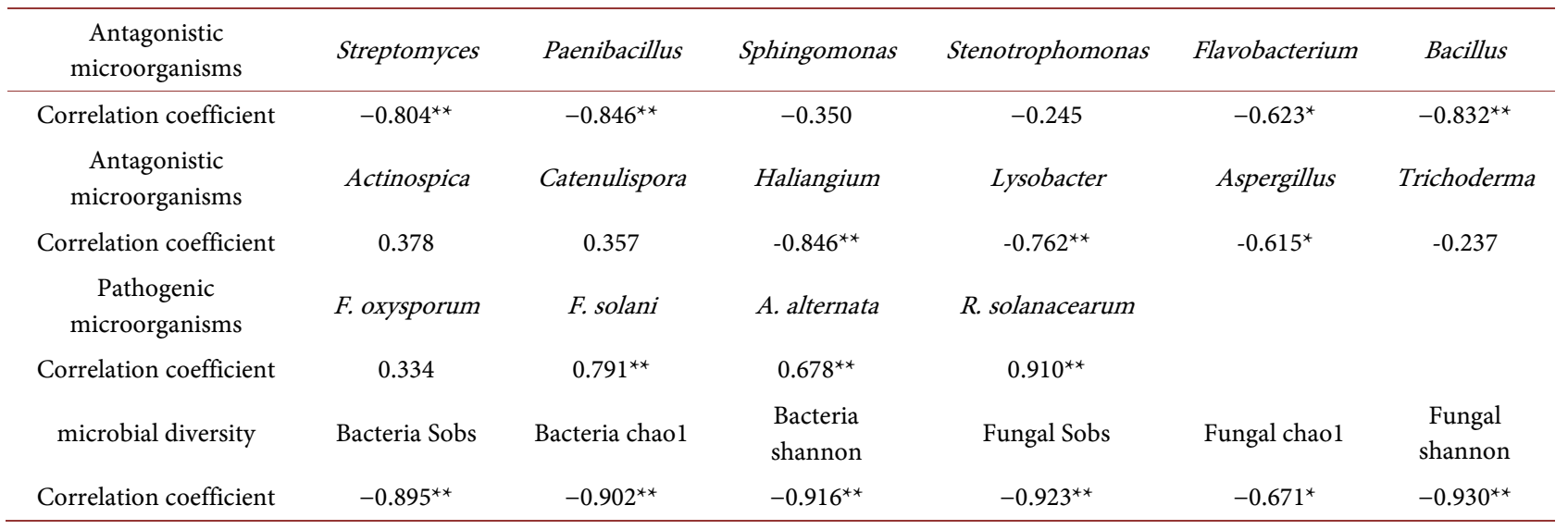

${ }^{*}$ and ${ }^{* *}$ indicate correlation is significant at $p<0.05$ and $p<0.01$.

Table S5. Spearman correlation analysis between disease index of tobacco bacterial wilt and soil physicochemical properties.

\begin{tabular}{ccccccccc}
\hline & $\mathrm{pH}$ & organic matter & total N & alkaline $\mathrm{N}$ & available $\mathrm{P}$ & available $\mathrm{K}$ & exchangeable Ca & exchangeable Mg \\
\hline Correlation coefficient & $-0.944^{* *}$ & $0.979^{* *}$ & $-0.851^{* *}$ & $-0.972^{* *}$ & $0.902^{\star *}$ & $-0.629^{*}$ & $-0.874^{* *}$ & $-0.909^{* *}$ \\
\hline
\end{tabular}

${ }^{*}$ and ${ }^{* *}$ indicate correlation is significant at $p<0.05$ and $p<0.01$. 